\title{
The Contribution of Cervical Dynamic Magnetic Resonance Imaging to the Surgical Treatment of Cervical Spondylotic Myelopathy
}

\section{Servikal Spondilopatik Miyelopatide Servikal Dinamik Manyetik Rezonans Görüntülemenin Katkısı}

\author{
Sedat DALBAYRAK ${ }^{1,}$ Onur YAMAN ${ }^{2}$, Mustafa Nevzat FIRIDIN ${ }^{3}$, Tevfik YILMAZ ${ }^{4}$, Mesut YILMAZ ${ }^{1}$ \\ ${ }^{1}$ Neurospinal Academy, Department of Neurosurgery, Istanbul, Turkey \\ ${ }^{2}$ Tepecik Education and Training Hospital, Clinic of Neurosurgery, Izmir, Turkey \\ ${ }^{3}$ Batman Dunya Hospital, Department of Neurosurgery, Batman, Turkey \\ ${ }^{4}$ Dicle University, School of Medicine, Department of Neurosurgery, Diyarbakır, Turkey \\ Corresponding Author: OnurYAMAN / E-mail: dronuryaman@yahoo.com
}

\begin{abstract}
AIM: Cervical spine is the most kinetic segment of the whole vertebrae. The radiologic imaging methods concern with the morphologic changes but give no functional data. At flexion, spinal cord strains, anterior osteophytic compression increases. At extension, spinal canal gets narrower, cord shortens and gets thicker, compression of posterior ligament gets abberant and cord compression increases.

MATERIAL and METHODS: 258 cervical spondylotic myelopathy (CSM) cases were scanned by conventional magnetic resonance imaging (MRI) and additionally dynamic MRI. Contributions of dynamic cervical MRI to the surgical plans and results were evaluated.

RESULTS: We had sagittal and axial T2W MR scans at flexion and extension, in addition to the neutral cervical MR imaging. We found that the AP diameter of spinal canal is increased $14.9 \%$ in flexion and decreased $13.4 \%$ in extension relative to the neutral MR imaging.

CONCLUSION: The changes of the cord compression and the transvers area of cord which is the most important prognostic indicator in spinal diseases and also the area of spinal cord and subarachnoid space can be detected via dynamic axial sections of MRI. Dynamic MR images may be helpfull in the decision making for the surgical treatment of CSM.
\end{abstract}

KEYWORDS: Cervical, Cervical spondylotic myelopthy, Dynamic, MRI

\section{öz}

AMAÇ: Servikal vertebra omurganın en hareketli bölümüdür. Radyolojik incelemeler omurga yapısı hakkında bilgi verse de fonksiyonel olarak herhangi bir veri sağlamamaktadır. Fleksiyon duruşunda omurilik gerilir ve ön tarafta yer alan osteofitik değişikliklerin basısı artmaktadır. Ekstansiyon duruşunda ise spinal kanal daralmakta, omurilik kısalmakta ve genişlemekte ve arka tarafta yer alan posterior ligamentlerin basısı artmaktadır.

YÖNTEM ve GEREÇLER: 258 servikal spondilopatik miyelopati hastası klasik MR görüntülerine ek olarak dinamik MR görüntüleri ile incelendi. Dinamik servikal MR görüntülemeleri ile cerrahi planlama ve sonuçları incelendi.

BULGULAR: Hastaların fleksiyon ve ekstansiyon duruşunda T2 ağırlıklı sagital ve aksiyel kesitlerine ek olarak nötr duruşta servikal MR görüntüleri elde edildi. Hastaların ön-arka spinal kanal çapı nötral duruşla karşılaştırıldığında fleksiyon duruşunda \%14,9 artarken, ekstansiyon duruşunda \%13.4 azalmaktadır.

SONUÇ: Spinal hastalıklarda spinal kord basısındaki değişiklikler ve spinal kanalın transvers alanındaki değişiklikler prognostik önem taşımaktadır. Spinal kord ve subaraknoid alan ölçümleri dinamik MRG ile elde edilen aksiyel kesitlerden elde edilebilir. Dinamik manyetik rezonans görüntülemeleri servikal spondilopatik miyelopatinin cerrahi kararını vermede yardımcı olmaktadır.

ANAHTAR SÖZCÜKLER: Servikal, Servikal spondilopatik miyelopati, Dinamik, MRG

\section{INTRODUCTION}

Cervical spondylotic myelopathy (CSM) and cervical spondylotic radiculopathy (CSR) are the most frequently observed conditions in individuals over middle age. Their frequency has increased with the increasing human life span and also with a more sedentary way of living. The most important factor in the increasing frequency of diagnosis is the use of imaging techniques, notably CT and MRI. It has become understood that the "senile walk" is indicative of the last stage of CSM (31).

CSM diagnosis requires a good medical history and a physical examination. CSM is indicated by thenar-hypothenar atrophy, motor defects in lower extremities along with spastic paresis, and ataxia related to the posterior column. In general, 
dermatomal pain is not a primary problem in these patients. However, pain in the back of the neck and occipital pain are the most frequent complaints (31).

Spinal cord involvement is not essential in all patients with spondylosis. Therefore, it is not justifiable to diagnose every individual who has spondylosis with CSM. Studies have indicated that cervical spondylosis is seen in more than $50 \%$ of individuals over 50 years of age; however, CSM is observed in only a small group of these patients. The presence of a congenital narrow canal is the most important factor in CSM development. It has been found that a congenital narrow canal is present in $72 \%$ of patients with myelopathies (3).

As a general rule, the correlation between radiological spondylotic changes and neurological deficits is weak (6). Furthermore, there is no correlation between the growth rate of osteophytes and neurological worsening.

The diagnosis of CSM is new and so is its treatment. Therefore, there is an abundance of controversial opinions regarding both the diagnosis and the mode of treatment. Making the diagnosis is the most important step in managing the condition. Radiological diagnosis, one of the steps in the diagnostic process, has varied depending on technological advancement. Many factors responsible for the etiopathogenesis were missed when diagnostic attempts were made with ordinary $\mathrm{x}$-rays and myelography and this led to inadequate diagnosis and treatment. As in other areas of neurosurgery, great distances have been covered in the diagnosis of CSM with the introduction of the CT. However, the technique is also inadequate in terms of showing all the relevant factors (particularly the dynamic ones) when the etiopathogenesis of CSM is considered (24). Today, the use of MR in cases of spinal pathology has kicked off the real work to be undertaken in the diagnosis and treatment of CSM. Dynamic MRI taken in flexion-extension positions, as a new examination method introduced with the advancement of MR technology, is believed to be useful in the imaging of the canal and cord that change with position, and in the imaging of the factors held responsible for the etiopathogenesis of CSM and instability, as well as in determining the treatment mode $(4,10)$.

\section{MATERIAL and METHODS}

This study aims to elaborate on the clinical characteristics, radiological findings, surgical operations, and outcomes of 258 CSM and/or CSR patients consisting of 123 females and 135 males who underwent surgical treatment. The age range was 32 to 73 years (mean age 51 years).

MR examinations were performed using a superconductive magnet phased-array spinal coil with a power of 1.5 Tesla. For each patient, images were taken in a neutral position in sagittal fast spin echo T2 (TR: 5000, TE: 110, FOV: $28 \mathrm{~cm}$, section thickness: $3 \mathrm{~mm}$, section interval: $0.3 \mathrm{~mm}, 384 \times 192$ matrix, twelve sections), sagittal spin echo T1 (TR: 500, TE: 14, FOV: $28 \mathrm{~cm}$, section thickness: $3 \mathrm{~mm}$, section interval: $0.3 \mathrm{~mm}$, $512 \times 224$ matrix, twelve sections), and axial gradient echo T2 (TR: 600, TE: 12, FOV: $18 \mathrm{~cm}$, section thickness: $3 \mathrm{~mm}$, section interval: $1 \mathrm{~mm}, 256 \times 192$ matrix, and at least four sections for each disc space). Later, flexion was obtained by placing rubber pillows below the occiput. As many pillows were used as the patient could tolerate (height of at least $15 \mathrm{~cm}$ ) without moving the patient. To avoid deterioration, patients were warned not to force themselves to move. Sagittal fast spin echo T2 sections and gradient echo axial T2 sections were also taken in this position. The MR device measurement software was used for canal diameter and area measurements.

\section{Measurements of Radiographic Examinations}

1. The canal diameter was measured in the lateral X-rays, and the anterior-posterior diameters were measured in the axial CT sections for all levels.

2. The flexion, extension, and neutral anterior-posterior diameters of the canal were measured in the axial MRI section for all levels.

3. Canal area measurements were performed for all levels and calculated with the MRI system's own calculation program.

We evaluated the clinical status of all our patients according to four common classifications (JOA, Nurick, Mann, and Symon and Launder) used for CSM.

We used various surgical approaches and techniques according to the number of levels involved in our cases, the location of the lesion (anterior or posterior), and the degree of instability.

Surgery was performed on 567 levels in 258 cases (an average of 2.2 levels per case). An anterior approach was used in 217 cases (84.1\%), a posterior approach in 33 cases $(12.8 \%)$, and an anterior + posterior combined approach in eight cases (3.1\%).

The follow-up periods for our patients ranged between 4 months and 71 months (25.5 months on the average). We evaluated the clinical conditions of all our patients according to four common classifications (JOA, Nurick, Mann, Symon and Launder) used for CSM.

\section{RESULTS}

\section{Results of Radiographic Examinations}

1. While the average bone canal diameter was $13.56 \mathrm{~mm}$ in ordinary x-rays, $9.84 \mathrm{~mm}$ was the average figure obtained via axial CT (difference $3.725 \mathrm{~mm}$ - narrower by $27.4 \%$ ), and it was concluded that it was more reliable to measure the bone canal with CT. The difference was found to be statistically significant (Student's t-test, $\mathrm{p}<0.001$; Wilcoxon signed-rank test, $\mathrm{p}<0.05$ ). The reasons for this are believed to be the quality differences seen in ordinary $x$-rays and the measurement errors when using ordinary $\mathrm{x}$-rays (especially when accompanied by osteophytes and PLLO).

2. When using MRI, which is superior to other imaging techniques for soft tissues such as discs, ligaments, etc., the AP 
diameter (7.04 $\mathrm{mm}$ on an average) was found to be narrower than that found with CT by $2.80 \mathrm{~mm}(28.5 \%)$ and $6.52 \mathrm{~mm}$ narrower than that found with ordinary $\mathrm{x}$-rays $(48.1 \%)$. It also supplied the most realistic information about the condition of the cord within the spinal canal. The difference between MRI measurements and X-ray measurements, as well as the difference between MRI measurements and CT measurements, were found to be statistically significant (Student's t-test, $\mathrm{p}<0.001$ and Student's t-test, $\mathrm{p}<0.001$, respectively).

3. On dynamic MR examinations, it was seen that the canal widened by an average of $1.05 \mathrm{~mm}(14.9 \%)$ during flexion $(8.09 \mathrm{~mm})$ and narrowed by $0.94 \mathrm{~mm}$ (13.4\%) during extension $(6.10 \mathrm{~mm})$ according to the average AP diameter values. The difference between the average flexion and extension MRI results was found to be $1.99 \mathrm{~mm}$ (Figures $1 \mathrm{~A}, \mathrm{~B}$; $2 A, B)$. The difference between the MRI measurements and $\mathrm{CT}$ measurements was found to be statistically significant (Student's t-test, $\mathrm{p}<0.001$, Wilcoxon signed-rank test, $\mathrm{p}<0.05$ ).

Dynamic MR examination was found to be particularly helpful in imaging the dynamic causes (instability) of CSM etiology. Although instability was suspected in $25.6 \%$ of the cases according to ordinary $\mathrm{x}$-rays, instability was found in $54.3 \%$ of cases after dynamic MR examinations. It was observed that retrolisthesis was disclosed especially frequently with hyperextension and that segmental excessive motion (e.g., kyphotic angulation) was disclosed with hyperflexion (Figure 3).

4. Routine spinal cord area measurements were performed during MR examinations. Canal area measurements as well as spinal cord area measurements were also performed.
Subarachnoid areas were calculated based on the differences between the first two measurements. As a result, it was concluded that this measurement was not yet sufficient, although the transverse spinal cord area measurements were based on the narrowest place (average $55.97 \mathrm{~mm}^{2}$ ), as indicated in the literature, and that transverse canal measurements should also be taken into consideration because they are rather variable in hyperflexion and hyperextension (average change amounts to 30\%) (Figure 4). The difference between these measurements was found to be statistically significant (Student's t-test, $\mathrm{p}<0.001$, Wilcoxon signed-rank test, $\mathrm{p}<0.05$ ).

Although cervical spondylosis is found in many elderly patients, it does not always cause myelopathy and/or radiculopathy. The most important mechanic factor in the etiology of CSM is the narrowing of the canal and the most frequent reason for this is congenital narrowness of the canal. The literature provides a ratio of congenital narrowness of the canal in patients with myelopathy as 72\% (10), and CSM developing on an underlying congenital narrow canal was found in 171 of our 258 cases (66.3\%). The most frequent anomaly was a short lamina, which was seen in 96 cases (56.1\%). We also observed the combined anomaly of a short pedicle, which we found in the 33 most severe CSM cases (19.3\% of the congenital narrow canal cases and $12.8 \%$ of all the CSMs).

\section{Clinical Evaluation}

The JOA, Mann, Symon, and Nurick evaluation scales were used in the clinical evaluation of the cases. Although they all had their insufficiencies, the Nurick and modified JOA scales were found to be the most suitable. The average preoperative JOA index of the cases was 10.8, the Nurick scale index was

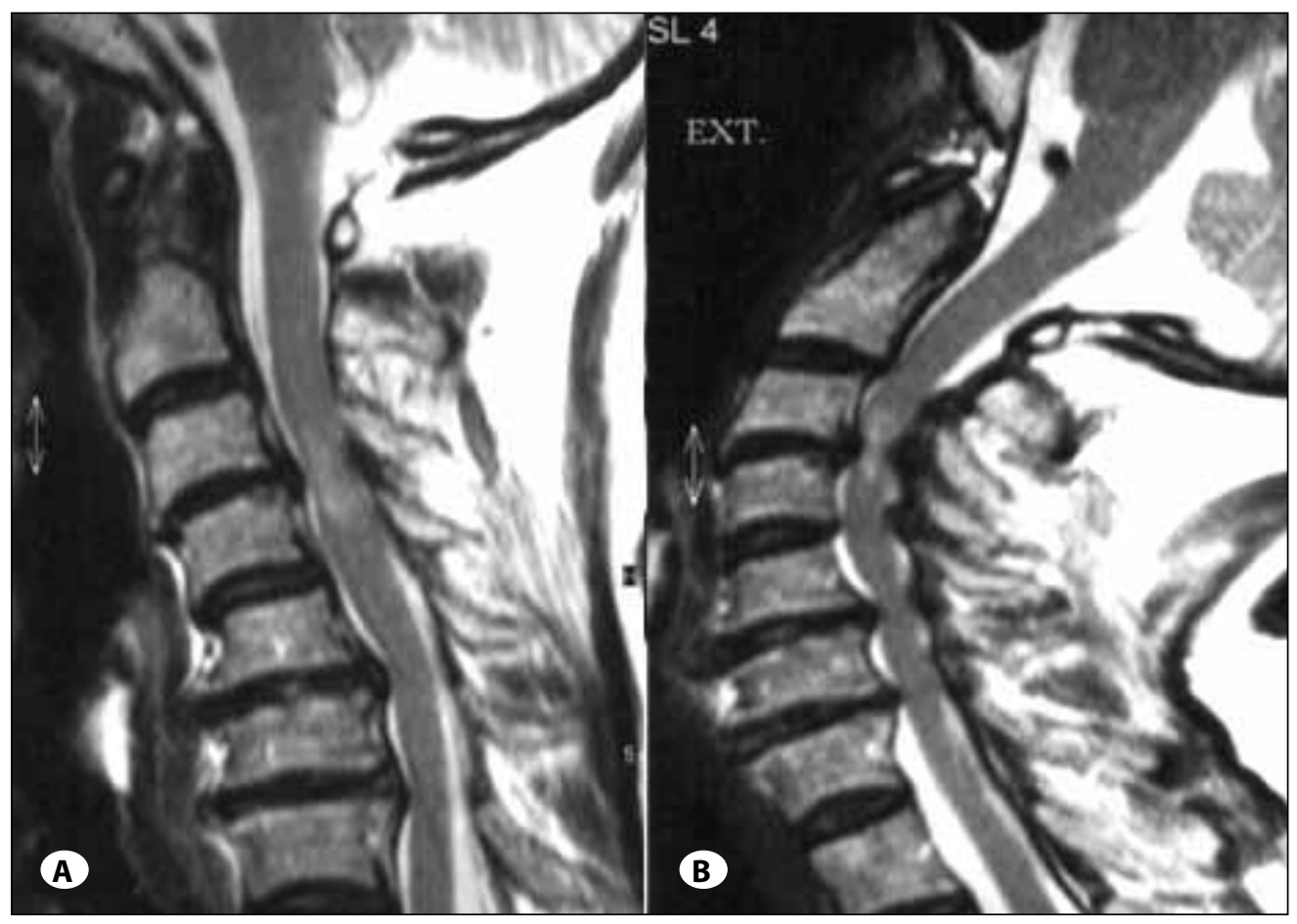

Figure 1: 66-year-old female. Dynamic MR examinations of case 4 in flexion (a) and in extension (b). A) Anteroposterior diameter values in flexion MRI: C3/4: $9.0 \mathrm{~mm}$, C5/6: 8.0mm, C6/7: $7.5 \mathrm{~mm}$. B) Anteroposterior diameter values in extention MRI: C3/4: $4.5 \mathrm{~mm}, \mathrm{C} / 6$ : 5.0mm, C6/7: $5.9 \mathrm{~mm}$. Spinal canal decreases in extension and provides the explanation for myelopathy. 
2.62, and the Symon scale index was 2.39. These preoperative scales are lower than the values in the literature (13) and the reason for this is improvements in early diagnosis with the introduction of MR into routine use, which has led to a clear display of the lesion, as well as the possibility of obtaining excellent results due to technological developments and surgical experience. Thus, there is no need to wait for the worsening of the patient's conditions, and surgery yields better outcomes.

\section{Surgical Approach}

Surgeons currently tend to perform the relevant surgery from the anterior because compression is great in both cervical disc disease and in CSM. Posterior laminectomy must be used only in cases of cervical myelopathy with a congenital narrow canal or in secondary narrow canal cases caused by hypertrophy of the posterior yellow ligament. With the development of technology, microsurgery devices (microscopes, etc.), and

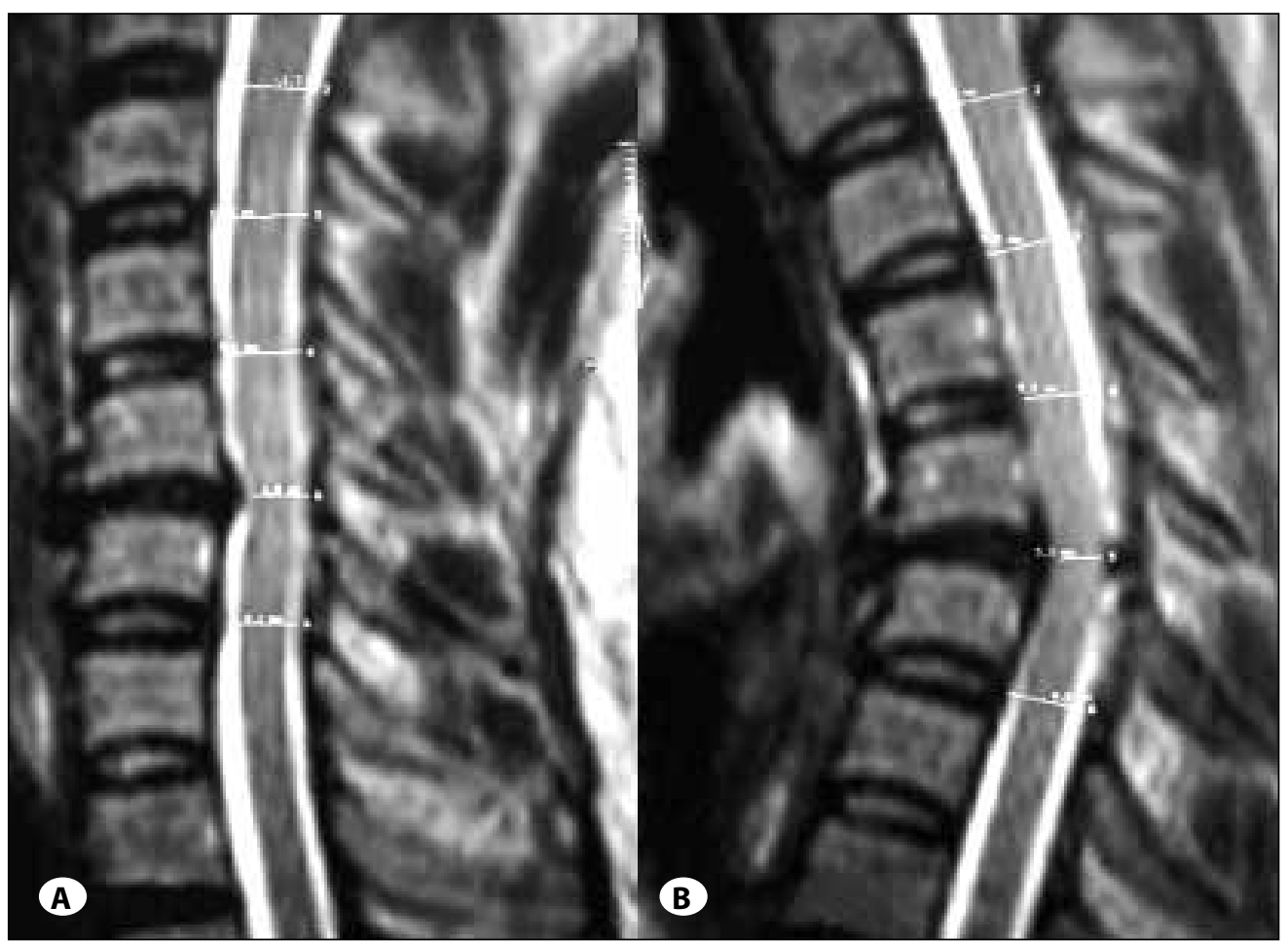

Figure 2: 37-year-old

female (Case 81). A) Sagital MR examination in neutral and $\mathbf{B}$ ) in flexion position. Kyphotic angulation was disclosed with hyperflexion. The diameter of $\mathrm{C} 5 / 6$ was calculated $5.7 \mathrm{~mm}, 5.0 \mathrm{~mm}$ and $6.8 \mathrm{~mm}$ in the neutral, flexion and extension positions respectively.

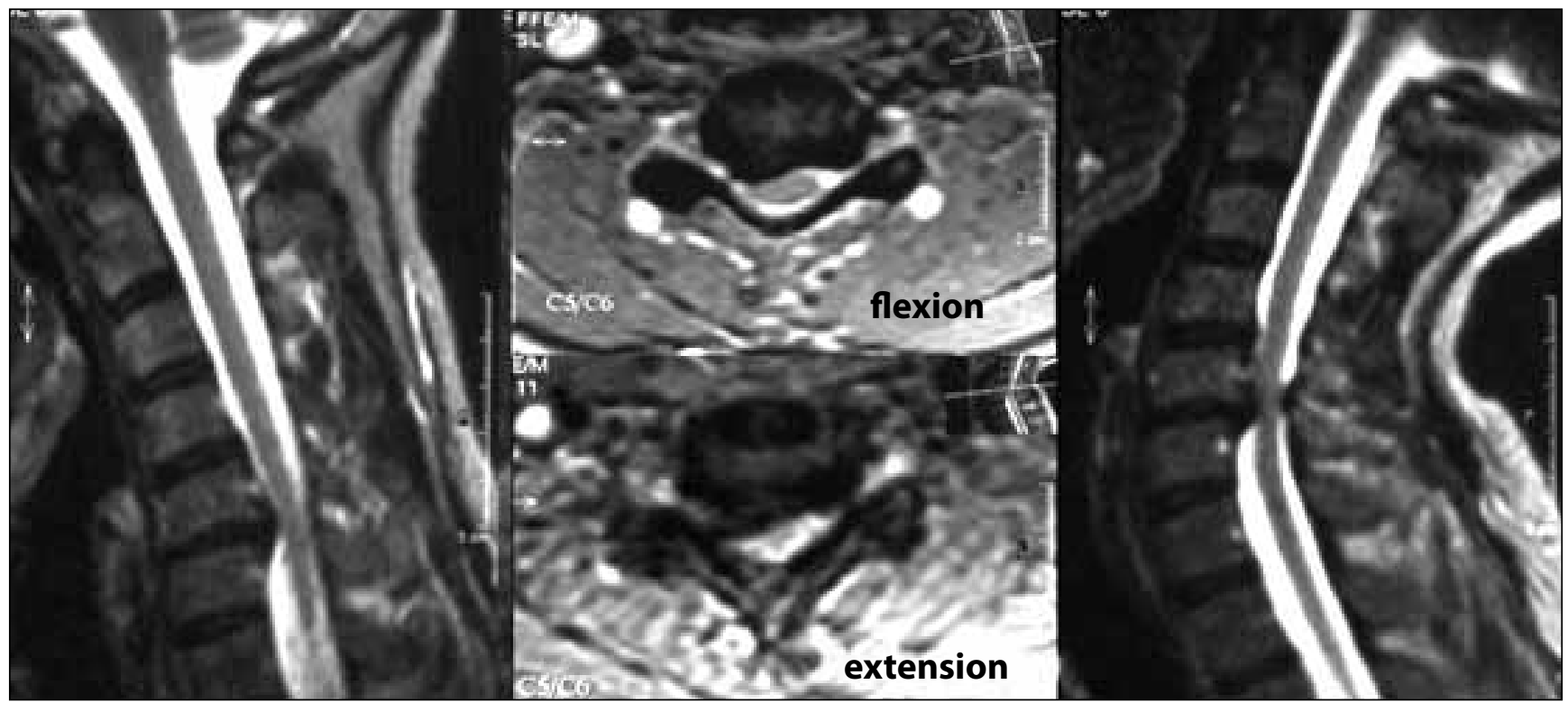

Figure 3: 46-year-old male (case 204). Sagital and axial dynamic MRI. Hard disc, osteophyte +OPLL. Spinal canal gets narrower at extension posture. 


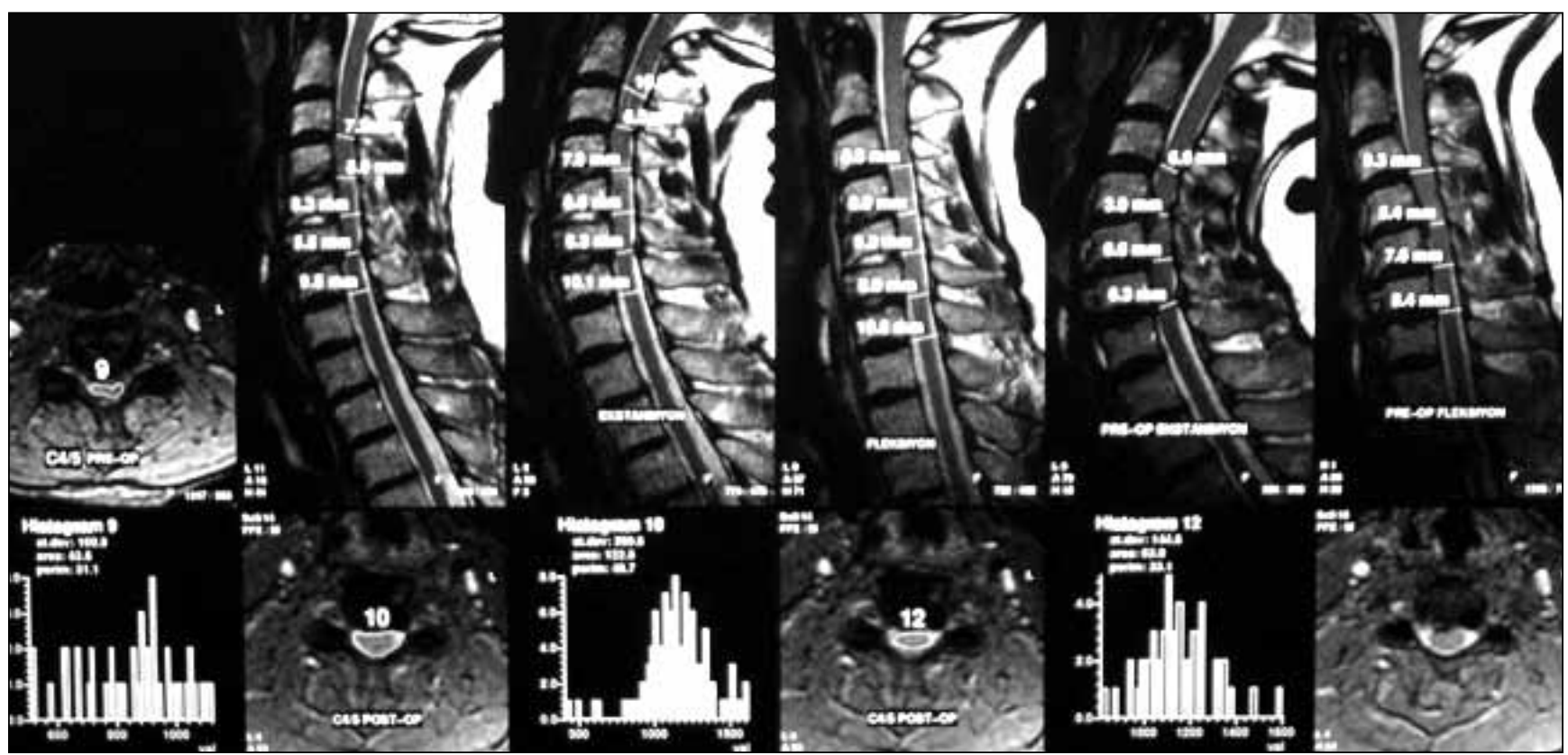

Figure 4: 60-year-old male (Case 74) Preoperative and postoperative antero-posterior and transvers sections of spinal area in the dynamic MRI.

rapid drills, anterior interventions are effectively performed on multiple levels without complications.

In the limited type of CSM, which is less frequent, it is easy to determine the surgical intervention and its mode. In such a case, it will suffice to perform the surgery within the boundaries of compression. Limited discectomy and fusion will be enough in patients with anterior compression in a single segment. However, there are ongoing discussions regarding the ideal surgical approach for compression in multiple levels. In such cases, anterior decompression and fusion, posterior laminectomy, or laminoplasty must be chosen (26, 27). The modern therapy mode for multisegmental CSM is microsurgical anterior decompression + graft and anterior plaque application (26).

Surgical intervention must be individually planned for each patient, considering multiple factors. Most current surgical series report that an anterior approach, especially vertebrectomy, provides the highest rates of clinical improvement. On the other hand, it is claimed that a posterior approach has significant advantages in those with multisegmental CSM (three or more segments). Laminectomy should be avoided in cases of flattening of the cervical vertebrae or reversing of the anatomical curvatures. Both anterior and posterior approaches are required for some patients (6). Biomechanical studies must be performed before attempting such an operation. Dynamic images, especially dynamic MRI examinations, and electrophysiological studies must be performed.

The level of decompression must be determined not only with clinical findings and ordinary $\mathrm{x}$-rays but also with CT and MRI, especially dynamic MRI examination. Instability criteria, such as retrolisthesis, can be found in a segment that has not been considered for intervention. It has been suggested that the greater the amount of decompression, the more successful the outcomes are (25).

Surgical morbidity and the effect on the mobility of the neck are not very great. Inadequate decompression also increases the possibility of postoperative worsening.

\section{DISCUSSION}

Cervical spondylotic myelopathy is the most frequent cervical spinal cord disease in individuals over 40 years of age (31). The mode of treatment that should be applied to these patients remains controversial. Improvements have been observed in the diagnosis and treatment of these lesions, particularly since the routine use of MRI.

Cervical spinal MR examinations are typically performed with the patient in a supine position by placing a receiver developed for spinal examinations under the neck and back of the patient. The neck is in a neutral position. Thus, the relationships between the vertebrae and the contours of the discs are imaged, with pathological changes receding to minimal levels. This insufficiency of routine neutral imaging became apparent in the early period of MRI application, and many investigators attempted various positions and maneuvers in an effort to make the information obtained show the symptomatic clinical condition more clearly $(2,11$, 14, 28). Taking images during flexion-extension has been the technique most commonly used for this purpose $(2$, $14,17,20,28,30)$. Changes in the foramen during rotation have also been examined for similar reasons $(11,16,19)$. The relationships of the discs and bone contours to CSM continue to be the subject of active investigation.

Imaging during flexion-extension can be performed through the use of various techniques. The simplest and most 
common method is lifting the occiput with supports placed underneath. Shifting the said support to the cervicothoracic junction is used to obtain extension, and takes are performed in these positions. Some investigators have even designed standard intermediate angles $(12,18,21)$. However, these are not commonly available or commonly used. Flexion and extension images can only be taken with sagittal $\mathrm{T} 2$ sequences or with axial T2 sequences added to them. These images can be taken rapidly to avoid artifacts of movement arising from the patient, who is placed in rather uncomfortable positions.

MRI findings have been evaluated in many studies in an attempt to select the mode of treatment and determine the prognosis for CSM patients $(5,7-9,22,23,29)$. The existence and amount of cord compression in static neutral images show a limited correlation with prognosis. A better prognosis can be ensured with the evaluation of pathological signal changes in the cord $(5,8,9,18,23,29)$. While these increased T2 signal areas reflecting myelopathy-myelomalacia are not specific to poor prognoses when they are minimal, they reflect chronic compressive changes in the stage of cystic myelomalacia that will not benefit from treatment, provided that they appear with sharp contours and bright red color $(5,21,23)$. A focally decreased T1 signal has been defined as another indication of poor prognosis (7). The CCF area surrounding the cord has also been reported correlate with poor prognosis (8).

All the radiological imaging methods involve morphological changes, rather than giving functional information. Both the mechanical pressure and vascular lesion increase during flexion and extension as a result of hypermotility. The spinal cord stretches during flexion. In addition, the anterior compression of the osteophyte is marked, and the anterior feeding of the cord is reduced. During the extension, however, the canal narrows, the cord shortens and thickens, and the compression of the posterior ligament becomes marked, while the compression increases with the retrolisthesis of the hypermobile segment, and a pincer effect is seen.

It is possible to measure the canal diameter, which changes depending on the ligaments and discs, as well as the sagittal bony diameter of the canal, and the diameter of the spinal cord can be measured using dynamic MRI, in contrast to the ordinary $\mathrm{x}$-rays obtained during flexion and extension.

It is possible to image the compression of the cord as it changes with movement; to measure the transverse cord area, which is the most important indicator of the prognosis in spinal pathologies; and to image the effect of movement on the unstable segment with dynamic axial images.

We have used dynamic cervical MR imaging since 1997. Currently, it is in routine use for every case with suspected instability, particularly for degenerative diseases, traumas, and craniovertebral junction anomalies. In this prospective study covering a period of 6 years, dynamic MR studies during hyperflexion and hyperextension were performed, as well as ordinary $\mathrm{x}$-rays, dynamic graphics, $\mathrm{CT}$, and neutral spinal $M R$, in 258 cases of cervical spondylotic myelopathy and/or radiculopathy.
During radiological evaluations, rather than the degree of spondylosis, the remaining area is important in showing the compression on and movement of the cord. In 1971, Adams developed a method for measuring the ROM (range of motion) of the cervical spine using flexion and extension films (1). Dynamic ordinary $\mathrm{x}$-rays have been used routinely for these patients for many years. In this study, we concluded that dynamic factors should not be determined only through dynamic conventional films because of measurement errors on ordinary $\mathrm{x}$-rays and the inability to image the compression on the soft tissues. We used dynamic MRI for all patients in our series.

\section{CONCLUSION}

In addition to the sagittal and axial dynamic MR images taken during flexion and extension, the correlation between the transverse area measurements must be established, and surgical planning must be based on this. The changes in cord compression and the transverse area of the cord, which are the most important prognostic indicators in spinal diseases, as well as the area of the spinal cord and subarachnoid space, can be detected via dynamic axial sections of MR images. Dynamic MR images may be helpful in the decision-making process regarding the surgical treatment of CSM.

\section{REFERENCES}

1. Adams CBT, Logue V: Studies in cervical spondylotic myelopathy: II. Movement and contour of the spine in relation to the neural complications of cervical spondylosis. Brain 94:569-586, 1971

2. Bell GR, Stearns KL: Flexion-extension MRI of the upper rheumatoid cervical spine. Orthopedics 14(9):969-973, 1991

3. Burrows HR: The sagittal diameter of the spinal canal in cervical spondylosis. Clin Radiol 14:77-86, 1963

4. Chen CJ, Hsu HL, Niu CC, Chen TY, Chen MC, Tseng YC, Wong YC, Wang LJ: Cervical degenerative disease at flexionextension MR imaging: Prediction criteria. Radiology 227: 136-142, 2003

5. Chen CJ, Lyu RK, Lee ST, Wong YC, Wang LJ: Intramedullary high signal intensity on T2-weighted MR images in cervical spondylotic myelopathy: Prediction of prognosis with type of intensity. Radiology 221(3):789-794, 2001

6. Cusick JF: Pathophysiology and treatment of cervical spondylotic myelopathy. Clin Neurosurg 37:661-681, 1991

7. Epstein JA, Carras R, Hyman RA, Costa S: Cervical myelopathy caused by developmental stenosis of the spinal canal. J Neurosurg 51:362-367,1979

8. Fukuoka M, Matsui N, Otsuka T, Murakami M, Seo Y: Magnetic resonance imaging of experimental subacute spinal cord compression. Spine 3(14):1540-1549, 1998

9. Golash A, Birchall D, Laitt RD, Jackson A: Significance of CSF area measurements in cervical spondylitic myelopathy. $\mathrm{Br} \mathrm{J}$ Neurosurg 15(1):17-21, 2001

10. Gore DR: Radiological evaluation of the degenerative cervical spine. In: Clark CR, (ed), The Cervical Spine. 3rd ed. Philadelphia, Pa: Lippincott-Raven, 1998:765-778 
11. Iai H, Moriya H, Goto S, Takahashi K,Yamagata M, Tamaki T: Three-dimensional motion analysis of the upper cervical spine during axial rotation. Spine 18(16):2388-2392, 1993

12. Karhu JO, Parkkola RK, Komu ME, Kormano MJ, Koskinen SK: Kinematic magnetic resonance imaging of the upper cervical spine using a novel positioning device. Spine 24(19): 2046-2056, 1999

13. MacDonald L, Fehlings MG, Tator $\mathrm{CH}$ : Multilevel anterior cervical corpectomy and fibular allograft fusion for cervical myelopathy. J Neurosurg 86:990-997, 1997

14. Mayfeld FH: Cervical spondylosis: A comparison of the anterior and posterior approaches. Clin Neurosurg 13: 181-188, 1966

15. Morimoto T, Okuno S, Nakase H, Kawaguchi S, Sakaki T: Cervical myelopathy due to dynamic compression by the laminectomy membrane: Dynamic MR imaging study. J Spinal Disord 12(2):172-173, 1999

16. Morio $Y$, Teshima R, Nagashima H, Nawata K, Yamasaki D, Nanjo Y: Correlation between operative outcomes of cervical compression myelopathy and MRI of the spinal cord. Spine 26(11):1238-1245, 2001

17. Muhle $C$, Bischoff $L$, Weinert $D$, Lindner V, Falliner $A$, Maier C, Ahn JM, Heller M, Resnick D: Exacerbated pain in cervical radiculopathy at axial rotation, flexion, extension, and coupled motions of the cervical spine: Evaluation by kinematic magnetic resonance imaging. Invest Radiol 33(5):279-288, 1998

18. Muhle C, Brossmann J, Biederer J, Grimm J, Mohr A, Heller M: Value of kinematic MRI in the evaluation of patients with exacerbated pain in cervical spine motion compared with static MRI. Rofo173(2):126-132, 2001

19. Muhle C, Metzner J, Weinert D, Falliner A, Brinkmann G, Mehdorn MH, Heller M, Resnick D: Classification system based on kinematic MR imaging in cervical spondylitic myelopathy. AJNR Am J Neuroradiol 19:1763-1771, 1998

20. Muhle C, Resnick D, Ahn JM, Südmeyer M, Heller M: In vivo changes in the neuroforaminal size at flexion-extension and axial rotation of the cervical spine in healthy persons examined using kinematic magnetic resonance imaging. Spine 26(13):E287-293, 2001
21. Muhle $C$, Weinert D, Falliner A, Wiskirchen J, Metzner J, Baumer M, Brinkmann G, Heller M: Dynamic changes of the spinal canal in patients with cervical spondylosis at flexion and extension using magnetic resonance imaging. Invest Radiol 33:444-449, 1998

22. Muhle C, Wiskirchen J, Weinert D, Falliner A, Wesner $F$, Brinkmann G, Heller M: Biomechanical aspects of the subarachnoid space and cervical cord in healthy individuals examined with kinematic magnetic resonance imaging. Spine 23:556-567, 1998

23. Naderi S, Ozgen S, Pamir MN, Ozek MM, Erzen C: Cervical spondylotic myelopathy: Surgical results and factors affecting prognosis. Neurosurgery 43(1):43-49, 1998

24. Panjabi MM, Dvorak J, Sandler A, Goel V, White AA: Cervical spine kinematics and clinical instability. In: Clark CR, (ed), The cervical spine. 3rd ed. Philadelphia, Pa: Lippincott-Raven, 1998:53-77

25. Saunders RL, Bernini PM: Cervical spondylotic myelopathy. Oxford: Blackwell Sci. Pub, 1992

26. Seifert V, Stolke D: Multisegmental cervical spondylosis: Treatmant by spondylectomy microsurgical decompression, and osteosynthesis. Neurosurgery 29:498-503, 1991

27. Seifert V: Anterior surgical approaches in multisegmental cervical spondylosis. In: Shmidek HH, Smith WH (eds), Operative Neurosurgical Tecniques. Vol: 2. Philadelphia: WB Saunders Co, 1995:1791-1804

28. Shippel AH, Robinson GK: Radiological and magnetic resonance imaging of cervical spine instability: A case report. J Manipulative Physiol Ther 10(6):316-322, 1987

29. Wada E, Yonenobu K, Suzuki S, Kanazawa A, Ochi T: Can intramedullary signal change on magnetic resonance imaging predict surgical outcome in cervical spondylotic myelopathy? Spine 24(5):455-461, 1999

30. Weng MS, Haynes RJ: Flexion and extension cervical MRI in a pediatric population. J Pediatr Orthop 16(3):359-363, 1996

31. Zileli M: Cervical spondylitic myelopathy. In: Zileli M, Ozer AF (ed), Surgery of spine and spinal cord. 1st ed. Adana: Nobel Publishing, 1997:315-343 